\title{
Speciality of Relationship between Turkey and Palestine
}

\author{
Wan Kamal Mujani \\ Universiti Kebangsaan Malaysia \\ Email: inamal@yahoo.com
}

Ahmed Y.M. Alahmed

Universiti Kebangsaan Malaysia,

Email: ahmed17w17@yahoo.com

\section{Eeman Mohammed Abbas}

Universiti Kebangsaan Malaysia

Email: anar_111@hotmail.com

Doi:10.5901/mjss.2015.v6n4s1p554

\begin{abstract}
The Turkish policy toward the Palestinian Cause relies on a number of considerations and bases, some of which have a historical dimension which extends to more than four centuries, that is, since the victory of the Ottomans over the Mamluks in the Marj Dabiq Battle in 1516. Some other considerations relate to the big civilization depth among the people of Turkey and those of Palestine. Further, there are mutual historical, religious and cultural bonds between the two peoples. What adds to all this is the great concern of the Turkish people for the Palestinian Cause especially that which concerns the Islamic holy places. Such concern can also be related to the Turks' attempt to politically lead and play a role in the region especially within the leadership vacuum in the Islamic World and the absence of the leading Islamic State which could adopt the nation's causes and concerns. Some of such Turkish considerations and bases could relate to the Turkish interests in the Arabic region as a whole, something that forms a big incentive for Turkey to direct its concerns and activities toward the Arabic East and develop its economic interests in the region.
\end{abstract}

Keywords: relationship; Turkey; Ottoman; Palestine;

\section{Introduction}

The Ottoman rule for Palestine continued for over four centuries, that is, since the Ottoman victory over Mamluks in the Battle of Marj Dabiq on 25 Rajab 922/24 August 1516, near the city of Halab in an area known as Marj Dabiq. Later on 20 January of the same year, the Ottoman army reached Gaza where the Ottomans led a last battle against the Mamluks under the leadership of Sinan Basha in the Sham region which completely became under the Ottoman sovereignty (Bayat, 2003). In this way, Palestine was under the Ottoman rule which divided it into three administrative units, namely Mutasarrifate al-Quds, Mutasarrifate Nablis and Mutasarrifate Akka (Abdulmonem, 2010).

In 1831, the governor of Egypt Muhammad Ali Basha revolted against Turkey. In the same year, by the leadership of his son Ibrahim, his army seized the city of al-Quds and all the Palestine territories. A few months later, a revolution started all over Palestine against Ibrahim Basha. At that time, al-Quds was one of the most important revolution centers. His rule lasted ten years. His withdrawal from Palestine was in 1841. By his return to Egypt, Palestine returned once again to the Ottoman rule (Al-Aref, 1994). Within this long history of Ottoman rule for Palestine, al-Quds had a special concern. Being ruled directly from Istana is evidence of its significance. Politically, it was the main center for Mutasarrifate al-Quds which comprised five districts, namely al-Quds district which had five sub-districts, Yafa district which consisted of two sub-districts, Gaza district which included three sub-districts, al-Khalil district which had two sub-districts and alSab' Well district which was composed of two sub-districts. These districts included three hundred and seventy nine villages and five big tribes. In 1840, the al-Quds had a counsel comprising all sects. In 1908, the al-Quds district was represented by three representatives in the Ottoman Parliament: two for al-Quds and one for Yafa. In 1911, a public counsel of five districts that the Mutasarrifate al-Quds included was formed in al-Quds (Al-Aref, 1994).

In the al-Quds, the religious and social institutions and learning centers received great concern from the Ottoman 
government which renovated and set them into work again. The Ottoman government endowed some land property so as their money would be spent on those institutions and centers. It had also assigned annual certain amounts of money to the al-Quds people (Rubye'a, 2010).

Al-Quds was cared about most in the reign of the Sultan Sulaiman the First (who was also known as the Sultan Sulaiman al-Qanuni 1520-1566) who re-built the city's fence where a number of gates still exist in the present time such as the gate of al-Amood, the gate of al-Sahira and the gate of al-Maghareba.

He also built al-Tur Masjid (1537). In addition, he paid great attention to the city's cultural production, in which the publications about the history of al-Quds increased. Among such publications of that era were the book of al-Hadra alUnsiya in the Holy Journey by Sheikh Abdulghani al-Nabulsi and the book of Swaneh al-Quds in My Journey to Wadi alQuds by Sheikh Mustafa Ismael al-Demyati. These were among the most important historical manuscripts that talked about the al-Quds City and its holy surroundings (Abdulmonem, 2010).

In his memoirs, the Sultan Abdulhamid the Second mentioned al-Quds emphasizing its importance for the general Muslims by saying: "It is our land at all times and place; it will remain so because it is among our holy cities and lies in an Islamic land; al-Quds must remain for us" (Harb, 1989). Therefore, in his reign, the Mutasarrifate al-Quds was in direct contact with the Grand Vizier in Istanbul so that he honored himself by preventing the Jewish spread in Palestine and specifically in al-Quds. Hogart, one of the Zionist experts in Middle East during the World War I, mentions that occupation was the main reason that pushed the Sultan in 1887 to make al-Quds a separate mutasarrifate from Damascus and its (i.e. al-Quds's) governors have direct contact with the Grand Vizier (Qasem, 2008).

Religiously, the life in al-Quds was characterized by religious tolerance among all its populations. That was due to the policy of the Ottoman State which adopted the Islamic way in dealing with non-Muslims who inhabited and adhered to the laws of the Islamic regions. The Ottoman administration granted the non-Islamic sects full freedom to practice their religious rituals. Those sects also had many privileges such as building churches, religious schools and missionary societies (Bayat, 2003).

This is evident from the description of the Turkish tourist Oliagli who visited the al-Quds in 1970. In his manuscript, he states that the al-Quds was inhabited then by forty-six thousand people, most of them Arab Muslims. In it, there were an Arman Church, three churches for the Romans, two temples for the Jews and two hundred and forty Mihrabs for prayers, seven buildings for the Hadith, ten for the al-Qur'an and forty schools for boys and Takaya (i.e. sufi worship centers) for seventy sufi ways (al-Aref, 1994). Therefore, the tolerance adopted by the Islamic World in the Ottoman era was a reason for the Jews to take the Islamic World a home in a time when they were subjected to persecution in Europe (Al-Hashimi, 2006). In 1860, the Ottoman State established the regular and legal courts as well as private courts. In 1859, it issued decrees to organize the legal Judiciary which was concerned with collecting fees in legal courts. In the reign of the Sultan Abdulaziz (1861-1876) a committee was formed from high ranked scholars to collect the legal rules and edit them in a magazine called Magazine of Legal Justice Rules. Such legal rules included 1851 items related to judiciary laws and justice rules (Ni'matallah, 2004).

Palestine underwent a number of crises in the long Ottoman rule due to either the bad administrative system or the bad situation of the state in general, a time when bribe and corruption were widespread in all state institutions. The deterioration of the Ottoman State especially in the nineteenth century and the beginning of the twentieth century has paved the way to the establishment of the Zionist project in Palestine. The Western states sought to create a colonialist entity in the heart of the Islamic World. This colonialist entity stood against the Islamic World unification and worked as a guarantee to the continuation of the Islamic World's weakness and disintegration. To put this colonialist project into practice, the idea of a buffer state in Palestine in London Conference (1905-1907) came into existence, where the executioners were the Jews in the land of Palestine. It was planned that this buffer state would be a friend state to the Western states that would rely on it to continue disintegrating the Islamic World, exploiting its energies and preventing any genuine process of civilization growth so that the region remains in a constant state of affiliation to the West.

In his book The Return of Islam (1976), the Orientalist Bernard Lewis states that "The lack of an educated modern leadership has so far restricted the scope of Islam and inhibited religious movements from being serious contenders for power. But it is already very effective as a limiting factor and may yet become a powerful domestic political force if the right kind of leadership emerges" (Al-Hasan, 2009).

The Ottoman rule for Palestine has lasted until 1917, that is, until it was fallen under the British occupation (AlHashimi, 2006). Further, the Treaty of Sevres on 10/8/1920 formally ended the affiliation of Palestine to the Ottoman State.

The most important phase of this long history of Palestine was that in which the Jews attempted to seize Palestine in the reign of the Sultan Abdulhamid the Second. The result of such phase in which the Jews played a significant role was the collapse of the Islamic Caliphate and the loss of the Sultan to his throne. The Jews exerted efforts to convince 
the Sultan to grant them some right in Palestine or giving them permission to emigrate to it. Theodor Herzl, the then father of Zionism in the world, provided a number of offers to the Ottoman State to save it from a deteriorating financial situation, exploiting its bad economic situation which made it burdened with external debt.

\section{Relationship Incentives and Basics}

The Turkish policy toward the Palestinian Cause relies on a number of considerations and bases, some of which have a historical dimension and some others relate to the big civilization depth among the people of Turkey and those of Palestine. Further, there are mutual historical, religious and cultural bonds between the two peoples. What adds to all this is the great concern of the Turkish people for the Palestinian Cause especially that which concerns the Islamic holy places. Such concern can also be related to the Turks' attempt to politically lead and play a role in the region especially within the leadership vacuum in the Islamic World and the absence of the leading Islamic State which could adopt the nation's causes and concerns. Some of such Turkish considerations and bases could relate to the Turkish interests in the Arabic region as a whole, something that forms a big incentive for Turkey to direct its concerns and activities toward the Arabic East and develop its economic interests in the region.

\subsection{Mutual historical, cultural and religious bonds between the two peoples of Turkey and Palestine as well as the civilization depth among them}

The Turkish Minister of Foreign Affairs, Ahmed Dawood Oglu, considers the return of Turkey to the East a natural matter; a continuation of the Ottoman long history in the East. He is of the opinion that the Arab-Turkey rapprochement is a natural historical return; that the obstacles meant against the Turkish openness toward the region have begun to collapse; that Turkey is going to pay attention to the region problems; that the walls between Turkey and the Arab World have begun to fall down and that the region is going to move smoothly with a new look toward cooperation and politicoeconomic integration, making it thus a mutual secure and prosperous environment. To him, what makes so possible is a radical solution to the Palestinian Cause. He says that Palestine has been and still is the main axes for the region's security and that Turkey will care for the region's details (Abbas, 2010).

The long period in which the Turks ruled Palestine has left a lot of conspicuous historical indicators that still existent until today. This long history is four centuries of mutual history between the Turks and the Arabs. The leaders of the Justice and Development Party have powerfully tried to regain that history in their present political discourse. Such attempt to regain the said history provides support for the Palestinian Cause specifically because of the Cause's presence in the Ottoman political memory and due to the event escalation in Palestine.

Thus, in his reply to the campaign against him in Israeli Press and Western Press as well as in some Turkish Press, Ordoghan has sought to bring back to memory the Sultan Muhammad al-Fatih who was the first to enter the Qustantinia and the Sultan Salim the First who launched the Ottoman widening campaign in the East. He states "If we keep silent against oppression, the bones of the Sultan Muhammad al-Fatih and those of the Sultan Salim the First gnash (Abbas, 2010).

Ordoghan also mentions the depth of the Turkish-Arab relationship while defending his country's politics toward the Arabic region. In his speech dated December 2012, Ordoghan states that "Turkey is obliged to care for Palestine, motivated by mere humane reasons. Palestinians and Syrians are brothers to the Turkish people. They have mutual history and culture and one doctrine.

Therefore, the new Ottomans, as they call themselves, act out of ethical and human values, for they defend oppressed people whose land is still occupied; oppressed people who are of a just Cause that transcends long decades without a just solution (Bakir \& Abu Amer, 2012). In this regard, Ali Koprulu, the Ambassador of Turkey in Jordan, stated that in addition to the historical, religious and cultural relations Turkish interest in the Palestinian Cause is also an ethical and human relationship. He tried to present the Turkish role in the region under the administration of the Justice and Development Party as an extension for the Ottoman State, its balance, international relations and strong presence in the political and human scene in the region.

\subsection{Grand public interest in Palestinian Cause}

The Palestinian Cause has a very big public interest in Turkey. It gains a lot of support and sympathy among the various groups of the Turkish people. Muhammad Gil, a Turkish political expert in Palestinian affairs, is of the opinion that there is no Cause around which the various groups of the Turkish people, whether Islamists, Secularists or Leftists, gather but the Palestinian Cause. It is a Cause that touches the heart of the Turkish people. During the modern history, it was the Cause 
that has gained the consensus of all the Turks with all their races, genders and orientations. Also, it constantly has a present public Islamic dimension in the Turkish mind. The Turkish Prime Minister and the leader of the Justice and Development Party, Ordoghan, has gained a large part of his popularity due to his support to the Palestinian Cause.

This public support from the Turkish people for the Palestinian Cause was a winning card in the hands of the Turkish Justice and Development Party which could employ this card in a good way to gain the Turkish public support for his policies and activities. The Party managed to do so through the Party leaders' daring stances and bitter criticism directed toward Israel and its aggressions on the Palestinian people (Saleh, 2010).

Although Palestine with its holiness is now strongly present at the Turkish official and public levels, this status has been present before the coming of the Justice and Development Party to authority. Palestine has always had a public consensus especially when the matter concerns the Islamic holy places in it. For example, In September 1980, the Turkish National Salvation Party represented by its leader Najm al-Din Erbakan launched a campaign titled 'Free al-Quds' in which one hundred thousand people participated and demanded the establishment of the Islamic State and freedom for al-Quds (Hilal, 1999).

The Turkish support for the Palestinian people has taken many forms among the most evident of which is the freedom fleet headed to Gaza on 29/5/2010 that aimed at breaking the Israeli siege. Most of the volunteers in the freedom fleet were Turkish, in which their numbers reached four hundred participants (Al-Tamimi, 2010).

That incident gained the Turkish stance a high validity in the Palestinian street. For the Turkish stance was coupled with a very high price: blood, which was poured when Israel attacked the fleet. In addition, Turkey was affected by that stance economically and militarily due to the negative effect occurred to its strategic alliance with Israel (Bakir \& Abu Amer, 2012).

\subsection{Turkey's attempt to fill the leadership vacuum in the Islamic World}

Due to the fall of the Ottoman Caliphate, the Islamic World lost the leader state which had a religious and legal power that was sufficient to qualify it to be in a leadership position for the Islamic civilization and that would make it acceptable to the Islamic countries and non-Islamic communities. This also led the Islamic countries to get away from the Islamic legacy and tradition as they have become nearer to the Western model in their establishments and structures (Huntington, 1999). Thus, nowadays, Turkey seeks to re-establish itself to qualify for that position it had previously occupied through its present concern for the central issues in the Islamic World, trying to prove that it is a state that could fill that position again. It therefore tries to get concerned with the Palestinian Cause and the Islamic holy places on Palestine. Also, being pushed by the adjacent geography of Palestine as well as by the mutual history and economic power, it attempts to play a key role in this regard. Turkey considers itself having the right to further its project toward a leadership position in the Islamic World. That is to say that it has the long history, population, economic growth, geography and military qualification. Among the Islamic countries, Turkey is also characterized by its wide historical bonds with Muslims in the Balkans, North Africa and the Central Asia (Huntington, 1999).

In addition to the above, the Islamic nation suffers from a leadership vacuum. This nation has become absent in its real effect in the international politics despite its rich religious potential as the cradle of religion or its great financial potential. The Arab and Islamic peoples still lack the real leadership that could prove its position in the international arena as a power capable of its own protection and having its own independent free will and decision.

Within the absence of such Islamic state and the prevalent vacuum, circumstances have become convenient for the appearance of the Turkish stance over other stances of the rest of the Arabic and Islamic countries especially the stance that concerns the Palestinian Cause. This Turkish stance gains Turkey increased support in the Arab street. Most of the Arab and Islamic peoples have become looking at Turkey as a real leader for them. Such feeling is evident in the supporting and sympathetic indicators in the Turkish cities, something that shows the significance, status and role of Turkey for all the Islamic World.

In addition to the above are the special support projects on the Turkish land that are in favor of the Palestinian right. This shows the embrace of Turkey to the issues that have a reactionary dimension in all the Islamic World. One example is the International Public Conference for the support of Palestine held in Istanbul on 22/5/2009, that is, during the period that succeeded the Israeli war on Gaza. The conference was organized by a number of institutions from various Islamic countries such as Muslim World League, Islamic National Congress, General Conference of Arab Parties, Arab National Congress, International Committee to Advocate Palestine and Break the Siege of Gaga, Humanitarian Relief Foundation from Turkey, Global Anti-Aggression Campaign and many other Islamic representative institutions. The conference logo was 'Toward a Constant Support for Palestine'. The conference was attended by hundreds of people from various Islamic countries as well as by representatives of civil community institutions. In that conference, Istanbul 
represented a gathering center for the supporters of Palestine from all over the Islamic World.

Therefore, in the last decade, the official Turkish performance inclined toward the concern for the hot issues in the political arena in the Arab and Islamic World in a way that furthers the Turkish orientation toward establishing its identity as a leader and pioneer state at the level of the Islamic World.

In this context, an Israeli study conducted by Begin-Sadat Center for Strategic Studies in Tel Aviv points out that Turkey seeks to lead the Islamic World, that the Justice and Development Party which is leading the Turkish government heads away from the West in favor of improving the relations with the neighboring Muslims and that it has ambitions to lead the region and the Islamic World. The study also states that Israel is daily critiqued from the Turkish Prime Minister in an attempt to please the Islamic World saturated by Anti-Israel emotions (Abu Daqqa, 2011).

\subsection{Playing a key role in the Middle East}

The Palestinian Cause is considered one of the most important causes in the Middle East that is in a state of political polarization at the regional and international levels. Turkey has understood this equation at the end of which international powers often stand with strategic interests in the region. The Palestinian Cause and the Arab-Israeli conflict form a powerful entry to Turkey to become one of the influencing and decision-making circles and to achieve a leadership position. In this way, Turkey attempts to regain its previous great position as it was a key and influencing state in all political events in the region. It always seeks to play a key role in regional conflicts where many elite groups in Turkey believe that the latter is capable of playing such role (Hussein, 2006).

Turkey endeavors in presenting solutions and suggestions for peace and to end regional conflicts with a focus on the Palestinian Cause and the Arab-Israeli conflict that are the most important central issues in the region that are paid attention to by the world. Thus, Turkey is active today with the political events going on the regional level. This is so in a time when Turkey re-reads the political arena in the region as a whole as it has a realistic understanding for the nature of the new transformations in the international relations. Thus, its politics has become heading toward entry into a muli-polar process that rules the world today. Its foreign policy is not any more restricted to one direction. In this way, it tries to benefit from all forms of Turkish power that qualify it to perform a strong influence in the region (Oglu, 2010).

Due to the existing developments in its stances with the central issues such as the Palestinian Cause, for instance, Turkish relations with Israel have passed a state of ebb and flow. Such developments in the Turkish stances raised support for Turkey and its public credit especially in the Arab countries beside which Turkey stood in their revolutions and defended their rights to determine their destinies and regain their rights. This can be observed from the poll carried out by the Turkish Economic and Social Studies Foundation (TESEV) between 19 October and 15 December 2011. The poll includes 2323 participants in sixteen countries among which are a number of Arab countries. $70 \%$ of the participants state the necessity of Turkey to play a bigger role in the region and that it has become more influential than the previous years. With regard to the Arab-Israeli conflict, $75 \%$ are of the opinion that Turkey must play a mediatory role in this conflict. $78 \%$ of the participants have a positive view of Turkey and its new politics.

As for democracy and human rights, $61 \%$ of the participants consider Turkey a good model. They expect it to become a first economic power in the region in the future. The researcher, expert in the Middle East and North African affairs in the International Strategic Research Organization (USAK), Gamze Coskun states "the survey satisfies Turkey's desire to play a positive role in the region".

In a report published by the Stratfor Foundation on 2/2/2009, the founder of the Foundation George Friedman observes that Turkey has a deep vision based on its being a Muslim state with a responsibility exceeding its national security; and it could rely on itself in that regard. He considers the US in need of Turkey these days. Based on this, Friedman notices that Turkey, being backed by Muslims, can enforce its power and regain its marine power. This vision is an expanding one. He also views that, in the Islamic World, Turkey is one of five main strong states that own economic and military capabilities enough to enforce external influence (Friedman, 2009).

Ahmed Dawood Oglu considers Turkey after the 9/11 events to have a new status in the world. This new status has two bases, namely intellectual and geographical. Geographically, Turkey has a strategic place in the world as it is a central country with various regional identities that cannot be homogeneous. Therefore, such mixed regional composition grants Turkey the power to negotiate on a number of areas and thus becomes more powerful. Oglu considers Turkey to be the ideal place in the world in that it is both an Asian and European country and is near to Africa at the same time. This means that it is not an ordinary country; and it should not identify itself in a reactive way as it is a country that lies on the verge of the Islamic and Western World. Further, its cultural and historical legacy makes it one of the world's attractions all over history. Oglu also expresses the priority of the Turkish future politics, objectives and role that it seeks to achieve by saying that "the Turks will have a central and active role everywhere they ruled, lived in or passed over (Al- 
Saruji, 2009).

With this context, the concern with the Palestinian Cause comes as an implementation to the politics of strategic depth which is one of the pillars of the Turkish foreign policy and among its priorities to achieve the just and comprehensive peace in the region. Since the Palestinian Cause has always been present in most of the wars and conflicts in the past decades due to the Israeli occupation, its being as such makes the region stay in a state of constant conflict and a spot of tension devoid of stability. This as such negatively affects the Turkish agendas and limits its mobility to achieve its strategic objectives in the region (Bakir \& Abu Amer, 2012).

The ambassador of Turkey in Jordan, Ali Koprulu has stated the extent of the significance of solving the ArabIsraeli conflict in the region as a whole. He views the Palestinian Cause as the basic issue, and the priority of solving it is the key to solving all problems of the Middle East. To him, it cannot remain pending forever. Its delay cannot but adds complication to the Cause day after day. In this regard, he considers the Turkish support as a right to the Palestinian people in establishing their state and living in it with full self rule.

The interest remains evident in the orientation of establishing a leadership for the region as well as the attempt to regain the historical role played in the past. Turkey tries to benefit from the leadership vacuum in the Islamic World as there are no genuine qualifications with any other Arab and Islamic country to fill the gap and move to the head, especially with the lack of legitimacy of the current dictator ruling regimes whose rules do not depend on democratic and Islamic bases. In these latter Arab regimes, the rule centers on the individual ruler representing thereby the utter dictatorship and injustice. Such regimes therefore lack the value, ethics, balance, freedom and democracy in their dealings with their people. In their home and foreign policy, such regimes totally contradict with the will and aspirations of the general people.

In its orientation toward leadership, Turkey also tries to play a key role in the disputes and conflicts in the region. It attempts to play a parallel role to that of the superpowers and the big countries that have some interests in the region whose interests and politics have been shattered due to the influence of those superpowers.

\section{Concluding Remarks}

The Turkish-Palestinian relations are characterized by a historical depth in such a way that makes such relations of a certain specialty based on many historical, religious and cultural considerations. The Turkish foreign policy adopts balance that protects its interests and foreign relations as it is a big state that constantly tries to establish a regional state of stability that helps achieve its interests and security. Previous studies show that Turkey seeks to establish conformity between its glorious past in the region especially that which concerns the Palestinian Cause and its aspirations toward a leadership role in the region as well as developing its economic interests.

\section{References}

Abbas, Thaeyr. (2010). Transformations of Turkish policy: interests or desires. Al-Sharq al-Awsat, June 18, 2010.

Abdulmonem, Baghdad. (2010). Al-Quds in the Ottoman era. Al-Bahethon. Retrieved on January 22, 2013 from the following World Web Site: www. albahethon.com.

Abu Daqqa, Ahmed. (2011). Ordoghan seeks the leadership of the Islamic world. Al-Bayan, July 18, 2011.

Al-Aref, Aref Basha. (1994). al-Quds History. (2nd edn.) Cairo: Dar al-Ma'arif.

Al-Hasan, Isa. (2009). Ottoman State: Establishment Factors and Disintegration Reasons. (1st edn) Amman: al-Ahlia Publication.

Al-Hashimi, Abdulmonem. (2006). Arab History Encyclopedia. (1st edn.), vol. 6, Beirut: Dar al-Hilal.

Al-Saruji, Muhammad. (2009). Turkey and the alternative leadership for the region. Al-Hiwar.net. Retrieved on Febuary 2, 2013.

Al-Tamimi, Nahida. (2010). Lack of leadership in the Arab world: Ordoghan as a Model. Al-Mothaqaf, June 6, 2010.

Bakir, Ali Hussein \& Abu Amer, Adnan. (2012). Turkey and Palestinian Cause in the Transformations of Arab Spring. Doha: Al-Jazeera Center for Studies.

Bayat, Fadhel Mahdi. (2003). Studies in Arab History in Ottoman Period. (1st edn.) Beirut: Dar al-Madar al-Islami.

Friedman, George. (2009). Ordoghan's revolution and the future of Turkish state. Al-Mostaqbal al-Arabi, March, 2009.

Harb, Muhammad. (1989). Ottomans in History and Civilization. (1st edn.) Damascus: Dar al-Qalam.

Hilal, Redha. (1999). Sword and Crescent: Turkey from Atatork to Ordoghan; Conflict between Military Institution and Political Islam (1st edn.), vol. 1, Cairo: Dar al-Shurooq.

Hussein, Yasser Ahmed. (2006). Turkey: The Search for Future. Cairo: al-Usra Library.

Ni'matallah, Ibrahim Muhammad. (2004). Al-Ramlah in the late period of Ottoman era 1281-1333/1864-1914 Through Registers of Legal Courts. (Master thesis, Islamic University, Gaza, 2005).

Huntington, Samuel. (1999). The Clash of Civilization and the Remaking of World Order (1st edn), vol. 1, Cairo: Dar Sutoor for Publication.

Oglu, Ahmed Dawood. (2010). The Strategic Depth: Turkey's International Position and Role. Doha: al-Jazeera Center for Studies; 
Beirut: Arab Scientific Publishers.

Qasem, Khairaiyah. (2008). Zionist Activity and Its Echoes (1908-1918). Beirut: Research Center.

Rubye'a, Ibrahim. (2010). Al-Khwaniq in al-Quds during Ottoman Era. Gaza. Journal of Islamic University. 18(1): 1-20. Saleh, Mohsen. (2010). Turkey and Palestinian Cause. Beirut: al-Zaytouna Centre. 